ABDI: Jurnal Pengabdian dan Pemberdayaan Masyarakat ISSN: 2656-369X (Print), 2684-8570 (Online)

Volume 3 No. 2, Desember 2021

http://abdi.ppj.unp.ac.id/index.php/abdi

Email: abdi@ppj.unp.ac.id

DOI: https://doi.org/10.24036/abdi.v3i2.192

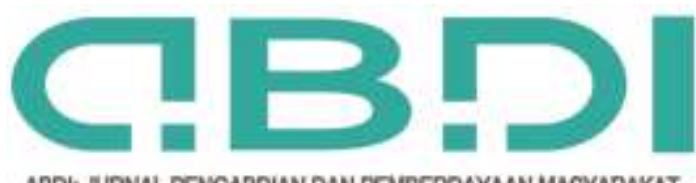

\title{
Peningkatan Kualitas Usaha Dendeng Jantung Pisang Menggunakan Teknologi Peniris Minyak
}

\author{
Yusri Nadya ${ }^{1}$, Nurlaila Hadayani ${ }^{2}$, Zainal Arif ${ }^{3}$ \\ ${ }^{1,2}$ Jurusan Teknik Industri, Universitas Samudra \\ ${ }^{3}$ Jurusan Teknik Mesin, Universitas Samudra \\ E-mail: nadyayusri@unsam.ac.id
}

\begin{abstract}
Abstrak
Desa Sidodadi memiliki sumber daya alam hayati yang sangat melimpah, salah satunya adalah pohon pisang, Kondisi tersebut dimanfaatkan ibu PKK gampong sidodadi sebagai Peluang usaha dengan mengembangkan usaha dendeng dari jantung pisang. Dari hasil wawancara dan diskusi, permasalahan yang dihadapi usaha ini adalah rendahnya kualitas produk, dimana produk dendeng jantung pisang masih banyak mengandung minyak. Pengabdian ini bertujuan untuk malakukan Perbaikan kualitas dendeng jantung pisang melalui penerapan teknologi alat peniris minyak. Hasil pengabdian ini berupa alat peniris minyak dengan spesifikasi bahan yaitu body speniris plat stainless steel, motor listrik 220 volt, kapasitas tabung $3-5 \mathrm{~kg}$, berat $8 \mathrm{~kg}$, diameter dan tinggi tabung 90x60x15 cmdari hasil uji coba alat didapatkan hasil yang cukup signifikan dimana waktu yang dibutuhkan untuk meiriskan minyak hanya 15 menit.
\end{abstract}

Kata kunci: Alat Peniris Minyak, Dendeng, Jantug Pisang

\section{Abstract}

Sidodadi village provides abundant natural resources one of which is banana trees. These resources are used by the lady of family welfare to be a business opportunity in their village. They increase the added value of the banana flower and process them into "dendeng", by replacing beef with a unique flavor. After conducting interviews and discussion among the ladies, the problem found in this effort is a low production quality, because the dendeng absorbs a lot of oil as a frying result. This community service program aims to improve the quality of banana flower dendeng through the implementation of oil drainer technology. The result is an oil drainer with material specification as follow: stainless steel plate drainer body; electric motor 220 volt; tube capacity is $3-5 \mathrm{~kg}$; drainer weight is $8 \mathrm{~kg}$; tube size is $90 \times 60 \times 15 \mathrm{~cm}$. the test result shows that the significant improvement, within time laps only 15 minutes.

Keyword: Banana Shoots, Dendeng, Oil Drainer Equipment

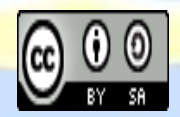

Received: 28 September 2021

Revised: 27 Desember 2021

Available Online: 28 Desember 2021

\section{Pendahuluan}

Pada umumnya dendeng terbuat dari olahan bagan baku daging sapi yang diiris tipis dengan tekstur kering dan renyah ( Sartika, dkk, 2018). Dendeng adalah jenis produk yang diawetkan yaitu melalui proses perebusan dengan menambahkan bumbu-bumbu dan penggorengan, tingginya harga jual dari dendeng daging ini menyebabkan hanya sebagian dari masyarakat yang mampu untuk membeli dedeng daging ini, sehingga hal ini membuat msyarakat terus mencari alternatif bahan baku pengganti daging untuk membuat dendeng sehingga biaya produksi mejadi lebih murah.(Novitasari dkk., 2012)

Desa Sidodadi merupakan salah satu kampung yang terletak di wilayah kecamatan Langsa Lama Kota Langsa memiliki luas wilayah $0,32 \mathrm{~km}^{2}$. Jumlah penduduk diperkirakan sekitar 587 jiwa, dengan kepadatan penduduk 112 jiwa (BPS, 2019). Desa Sidodadi memiliki sumber daya alam hayati yang sangat melimpah, salah satunya adalah pohon pisang. Pohon pisang ditanam oleh 
setiap penduduk disekitar rumah mereka. Mereka mengambil manfaat dari pohon pisang ini hanya daun dan buah pisang, sedangkan jantung pisang banyak yang terbuang sia-sia. Kelompok usaha PKK Desa Sidodadi memanfaatkan jantung pisang ini untuk diolah menjadi dendeng dengan rasa dan tekstur yang hampir dendeng dari daging. Kandungan gizi yang terdapat dalam jantung pisang juga sangat banyak sepeti protein;mineral, fosfor, kalsium, besi, vitamin A, b1, C, jantung pisang juga kaya akan serat pangan, dimana serat ini sangat dibutuhkan oleh, terutama pencernaan (Pertanian, 2010)

Proses pembuatan dendeng jantung pisang terdiri dari beberapa tahapan, yaitu proses pencahahan jantung pisang, pencucian, perebusan, penghalusan, pencetakan, penjemuran, penggorengan, dan penirisan minyak hasil penggorengan. proses penirisan minyak sangat mempengaruhi kualitas dan lamanya pnyimpanan (Muntasir dkk., 2018), Dari hasil wawancara dan diskusi, permasalahan yang dihadapi usaha ini adalah rendahnya kualitas produk, dimana produk dendeng jantung pisang masih banyak mengandung minyak. Minyak goreng yang tersimpan dalam jumlah banyak pada gorengan akan meningkatkan risiko masalah kesehatan sehingga diperlukan teknik untuk mengeluarkan minyak goreng yang berlebihan pada gorengan (Budiana dkk., 2020), ini dikarenakan proses penirisan masih dilakukan secara sederhana seperti yang terlihat pada Gambar 1.

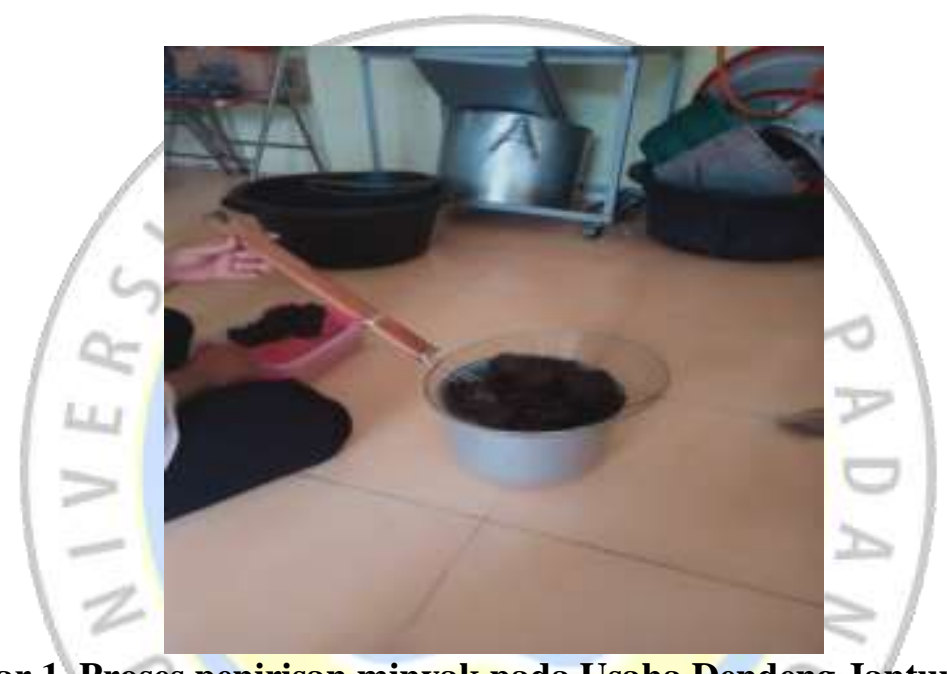

\section{Gambar 1. Proses penirisan minyak pada Usaha Dendeng Jantung pisang}

Dari Gambar 1. terlihat hasil penggorengan dendeng jantung pisang ditiriskan secara manual yaitu menggunakan rege, kemudian diangin -anginkan sehingga proses penirisan dengan cara ini membutuhkan waktu 24 jam dan hasil akhir yang tidak maksimal karena dendeng masih mengandung minyak, menurut Sari dkk., 2013, proses penirisan secara sederhana berupa saringan rege dan dialas dengan tissu atau koran sangat tidak efektif dan memelukan waktu yang lama agar minyak dapat tertiris, dan hasil yang diperoleh juga tidak sempurna dimana masih terdapat minyak yang melekat, hal ini menyebabkan kualitas dendeng cepat turun, serta masa penyimpanan dendeng yang kurang lama.

Dari gambaran tersebut maka permasalahan yang dialami kelompok usaha PPK Desa Sidodadi adalah:

1. Proses penirisan masih menggunalan alat sederhana, yaitu mengguakan peniris niru dan didiamkan sampai minyak turun

2. Proses penirisan membutuhkan waktu yang lama yaitu 1 hari

3. Kandungan minyak pada dendeng jantung pisang masih banyak, ini menyebabkan rendahnya kulitas dendeng jantung pisang 


\section{Metode Pelaksanaan}

Kegiatan Pengabdian Kepada Masyarakat (PKM) dilaksanakan oleh tim pengabdian dari Fakultas Teknik yang terdiri dari dosen Teknik Industri dan Teknik Mesin, dan sebagai mitra pengabdian ini adalah ibu-ibu PKK Khatulistiwa Desa Sidodadi Kota Langsa, kegiatan pengabdian ini berada dalam pengawasan Lembaga Penelitian Pengabdian Masyarakat dan Penjaminan Mutu (LPPM-PM) Universitas Samudra, kegiatan ini berlangsung mulai dari bulan juli sampai dengan Oktober tahun 2021.

Kegiatan (PKM) dimulai dengan temu ramah dengan Mitra, mendiskusikan komponenkomponen dan volume alat yang diinginkan Mitra. Tahap berikutnya adalah menentukan disain yang sesuai dan fabrikasi produk., desain alat peniris minyak seperti telihat pada gambar 2. Tahap selanjutnya adalah uji coba lapangan dan tahapan akhir adalah penyerahan alat peniris miyak kepada mitra.

Berdasarkan uraian permasalahan dari mitra maka penyelesaian permasalahan yang ditawarkan oleh tim pengabdi adalah membuat alat peniris minyak dengan mekanisasi yang lebih modern, dimana dilengkapi dengan pengaturan waktu penirisan sehingga bisa disesuaikan dengan kebutuhan. Mesin peniris minyak sangat efektif dan lebih efisien, sehingga dapat menigkatkan hasil prosuksi menjadi 5 kali lipat dibandingkan dengan sistem (Suriadi dkk., 2020). Efesien waktu menggunakan penirisan minyak pada makanan menggunakan alat Spinner ergonomis bisa mencapai 100\% (Handayani., 2020).

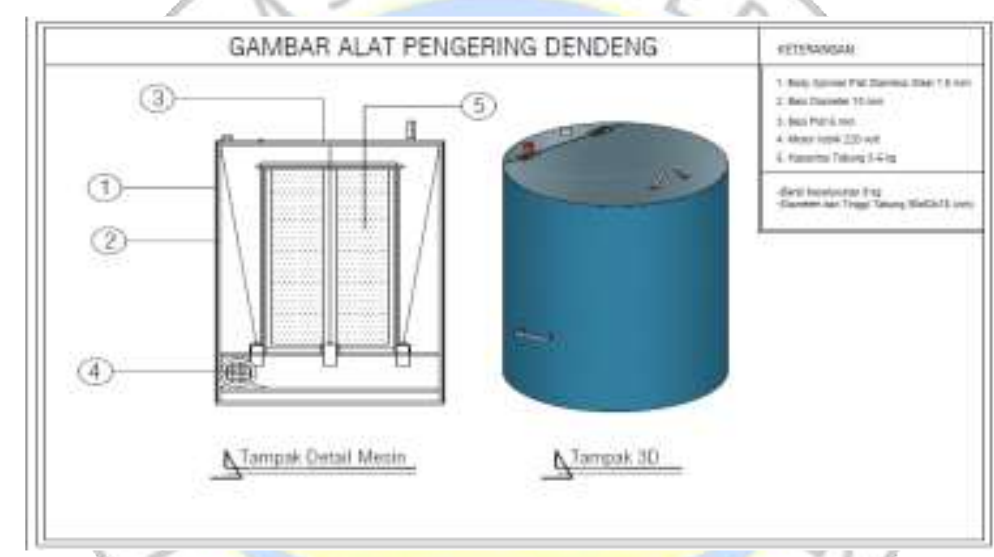

Gambar 2. Desain Alat Peniris Minyak Dendeng Jantung Pisang

Gambar 2. merupakan desain dari alat peniris minyak untuk dendeng jantung pisang yang dirancang berdasarkan kebutuhan mitra dilapangan.

\section{Hasil dan Pembahasan}

Tahapan awal dari kegiatan ini adalah pembuatan atau fabrikasi alat peniris minyak untuk dendeng jantung pisang.

Tabel 1. Spesifikasi bahan alat Peniris minyak

\begin{tabular}{clcc}
\hline No. & \multicolumn{1}{c}{ Material/Bahan } & Dimensi & Satuan \\
\hline 1 & Body Speniris Plat Stainless Steel & 1,5 & $\mathrm{~mm}$ \\
\hline 2 & Besi diameter & 10 & $\mathrm{~mm}$ \\
\hline 3 & Besi Plat & 5 & $\mathrm{~mm}$ \\
\hline 4 & Motor listrik & 220 & $\mathrm{volt}$ \\
\hline 5 & Kapasitas tabung & $3-5$ & $\mathrm{~kg}$ \\
\hline 6 & Berat keseluruhan & 8 & $\mathrm{~kg}$ \\
\hline & Diameter dan tinggi tabung & $90 \times 60 \times 15$ & $\mathrm{~cm}$ \\
\hline
\end{tabular}


Tabel 1. merupakan spesifikasi dari bahan alat peniris minyak untuk dendeng jantung pisang, komponen - komponen dan volume alat yang diinginkan mitra yaitu kapasitas keseluruhan sebesar $8 \mathrm{~kg}$, kapasitas tabung $3-5 \mathrm{~kg}$, body spinner plat stainless $1,5 \mathrm{~mm}$, besi diameter $10 \mathrm{~mm}$, besi plat $5 \mathrm{~mm}$, motor listrik 220 volt, proses pabrikasi di lakukan pada bengkel Cimita Agung, proses pembuatan alat peniris minyak dendeng jantung pisang seperti terlihat pada gambar 3 .
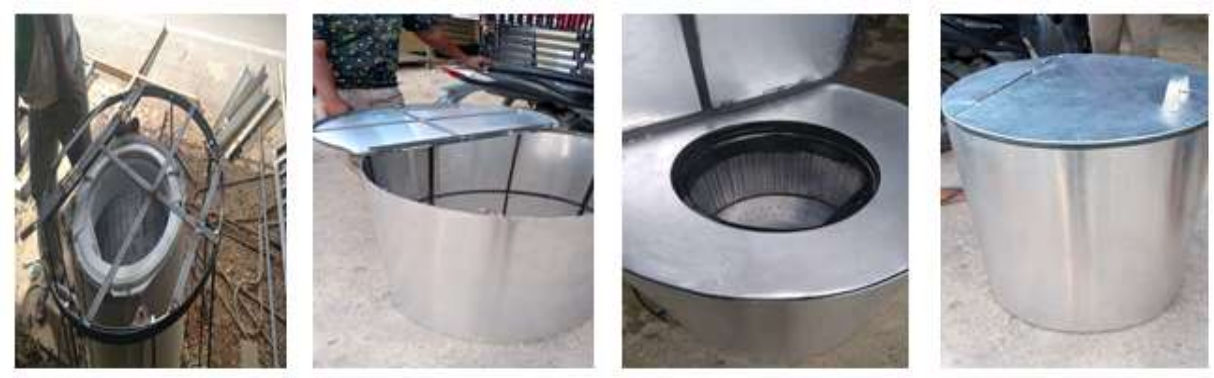

\section{Gambar 3. Proses Pembuatan Alat Peniris Minyak}

Setelah proses fabrikasi selesai tahap selanjutnya pendampingan cara penggunaan alat peniris minyak dan uji coba alat peniris minyak kepada mitra, seperti yang terlihat pada Gambar 4. Kegiatan ini dilaksanakan pada usaha dendeng Jantung Pisang PKK Katulistiwa Desa Sidodadi kecamatan Langsa Lama Kota Langsa pada Tanggal 23 Agustus 2021. Tujuan dari kegiatan ini adalah mitra mampu menggunakan alat peniris minyak dengan baik dan untuk mengetahui tingkat keberhasilan alat peniris minyak.
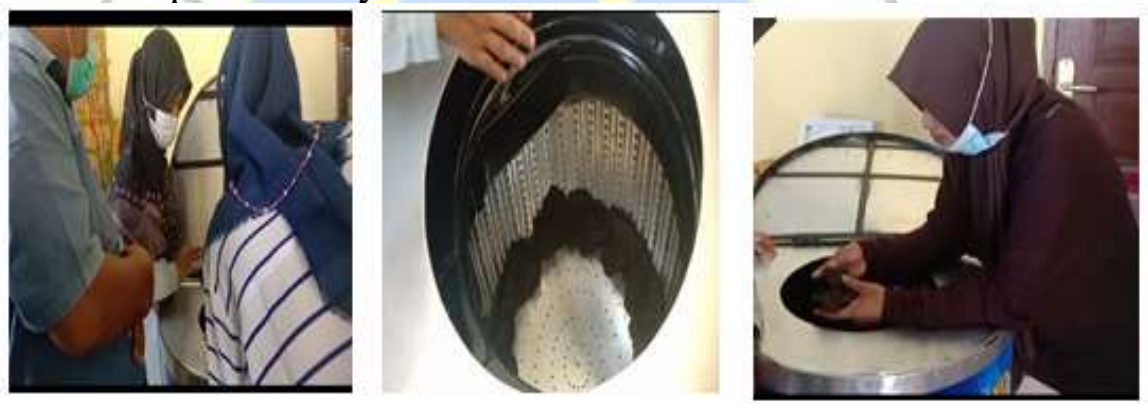

\section{Gambar 4. Pendampingan dan Uji Coba Alat Peniris Minyak oleh Mitra}

Dari hasil uji coba alat peniris minyak, ternyata alat peniris minyak ini dapat berfungsi dengan baik dan mudah untuk dioperasikan, kualitas dendeng jantung pisang yang dihasilkan juga jauh lebih kering dibandingkan dengan proses penirisan yang selama ini dilakukan oleh mitra, dan proses penirisan menggunakan alat peniris minyak ini hanya membutuhkan waktu 15 menit, sehingga sangat menghemat waktu produksi dimana ketika menggunakan peniris manual dibutuhkan waktu 24 jam untuk meniriskan minyak pada dendeng jantung pisang.

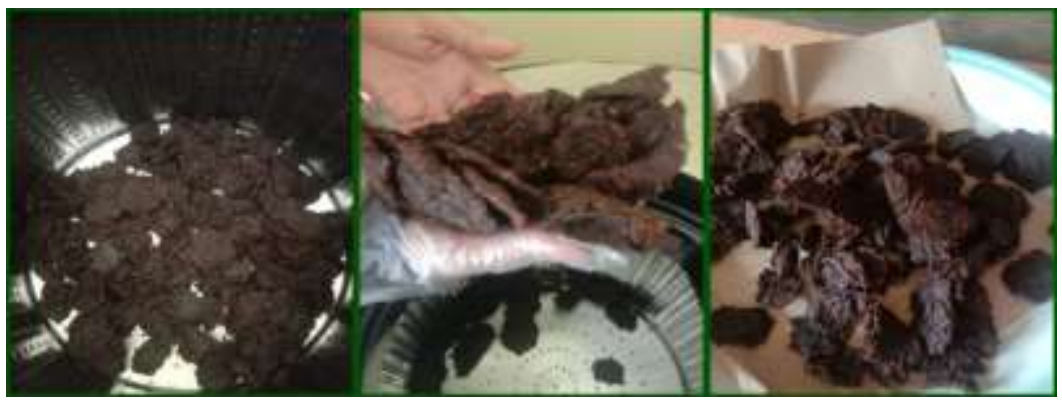

Gambar 5. Hasil dendeng jantung pisang dengan menggunakan alat peniris minyak 
Dari gambar 5. Terlihat bahwa kualitas dendeng jantung pisang yang dihasilkan jauh lebih baik dikarenakan dendeng jantung pisang menjadi lebih kering, sehingga umur simpan dendeng jantung pisang lebih tahan lama.

Langkah terakhir dari pengabdian ini adalah penyerahan alat dari tim pengabdi ke mitra agar dapat digunakan oleh mitra untuk meningkatkan pendapatan dan jumlah produksinya. Dokumentasi kegiatan pendapingan , uji coba alat dan serah terima alat dapat dilihat pada Gambar 6

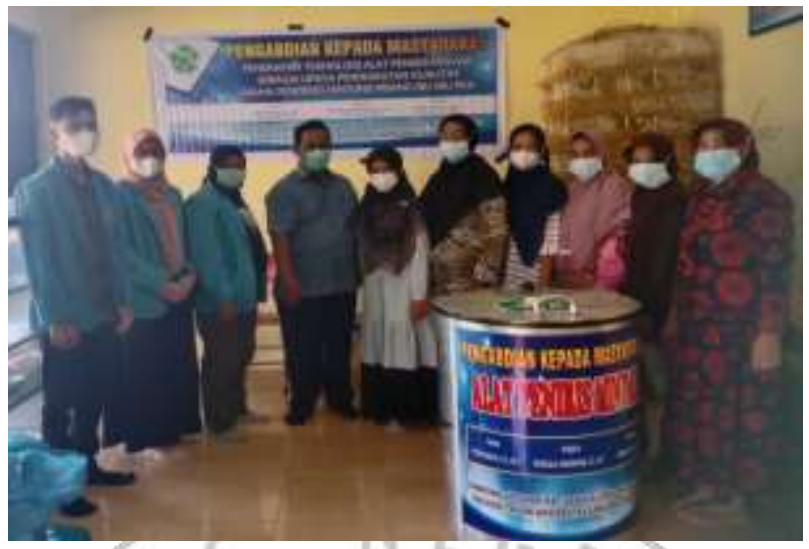

\section{Kesimpulan}

\section{Gambar 6. Penyerahan Alat Peniris Minyak pada Mitra}

Alat peniris minyak yang telah dirancang berfungsi dengan baik dan mampu mempercepat proses penirisan minyak, dimana proses penirisan hanya membutuhkan waktu 15 menit, dan kualitas dendeng jantung pisang menjadi lebih baik dikarenakan dendeng jantung pisang menjadi lebih kering.

\section{Daftar Pustaka}

Budiana, B., Darmansyah, F. A., Mahdaliza, R., Nakul, F., \& Putra, I. Z. (2020). Analisis Pengaruh Penggunaan Mesin Peniris Gorengan Terhadap Kualitas Gorengan. Journal of Applied Electrical Engineering, 4(1), 20-23.

BPS, (2019). Kecamatan Langsa Lama Dalam Angka

Novitasari, Afifah. Afin Ambarwati M.S. Apriliani Lusia W. Dewi Purnama Sari. Erlyn Hapsari. Nurul Devi Ardiyanti. (2013). Inovasi Dari Jantung Pisang ( Musa spp .).Jurnal KesMaskaJuli

Handayani, C. (2020). Analisis Pengurangan Kadar Minyak Menggunakan Alat Spinner yang Ergonomis. Sainstek: Jurnal Sains dan Teknologi, 12(2), 85. https://doi.org/10.31958/js.v12i2.2430

Muntasir, M., Purnawan, S., \& Syahdan, M. (2018). Penerapan Alat Peniris Serbaguna Model Silinder Sistem Sentrifuse Untuk Meningkatkan Mutu Dan Higienis Produk Kerupuk Jagung Kelimutu Sikumana Kota Kupang. Jati Emas (Jurnal Aplikasi Teknik dan Pengabdian Masyarakat), 2(1), 50-55.

Pertanian, P. P. dan P. T. P. B. P. dan P. P. K. (2010). Dendeng Jantung Pisang. Makanan Murah Sarat Gizi $P d f$.

Sari, Sanny Andjar, Dayal Gustopo, S. I. (2013). Untuk Peningkatan Kualitas Produk Pada Sentra. Industri Inovatif, 3(1), 49-51.

Suriadi, K., Atmika, A., Negara, P., \& Komaladewi, S. (2020). Pengabdian mesin peniris minyak abon. Buletin Udayana Mengabdi, 19(April), 187-191.

Winda Sartika, Elfi rahmi, Ida Indrayani, Rahmi Wati, A. S. (2018). Perbaikan Kemasan pada Dendeng Jantung Pisang. September, 223-227. 